\title{
"WHAT HAPPENS THERE ... FOLLOWS US HERE": Resettled but Still at Risk: Refugee Women and Girls in Australia
}

\author{
Linda Bartolomei, Rebecca Eckert, and Eileen Pittaway
}

\begin{abstract}
UNHCR's Women at Risk Program is designed to identify and respond to refugee women at extreme risk in countries of asylum who are in desperate need of resettlement. Many women who have been resettled under this program have been raped or faced forced engagement in survival sex, forced marriage, pregnancy, and childbirth as a result of rape. Drawing on a decade of research undertaken by the authors across 18 international sites, this article explores the experience of refugee women at risk resettled to Australia. It discusses the impacts of sexual violence on their settlement, including those of shame and stigma. It identifies that, while for some women at risk, resettlement offers hoped for safety and protection, for others the abuses they faced prior to resettlement resurface and are compounded by new risks and violations of their rights. It introduces a risk assessment tool designed to assist service providers to identify and respond to these risks.
\end{abstract}

\section{Résumé}

Le programme d'aide aux femmes dans les situations à risque du Haut Commissariat des Nations Unies pour les Réfugiés identifie et répond aux besoins des femmes réfugiées qui courent de sérieux risques dans leur pays d'accueil, et qui ont un urgent besoin d'être réinstallées ailleurs. Plusieurs femmes qui ont profité de ce programme, ont été des victimes de viol ou ont été obligé d'avoir recours à des rapports sexuels de survie, à des mariages forcés, à des grossesses et à des accouchements suite d'un viol. En se basant sur une décennie de recherches menées par les auteurs dans dix-huit sites à travers le monde, cet article explore les expériences de femmes à risque qui ont été réinstallées en Australie. On y considère l'impact des violences sexuelles subies avant le déplacement sur leur nouvelle installation, incluant le sentiment de honte et la stigmatisation. Alors que pour certaines femmes à risque, le déplacement offre une bonne sécurité et une bonne protection, l'étude démontre que pour d'autres les violences sexuelles subies refont surface après le déplacement et s'ajoutent à de nouveaux risques et à de nouvelles négations de leurs droits. Cet article propose donc une méthode pour évaluer les risques dans le but d'aider les différents fournisseurs de services à identifier et à répondre à ce type de risques.

\section{Introduction}

Men are affected in the war because men get killed, but women and children, they [rape] the women, they rape the little girls and mistreat the children. Do you understand?

$$
\text { -Resettled refugee woman (2008) }{ }^{1}
$$

The many risks and human rights abuses experienced by refugee and displaced women and girls in conflict, during flight and in camps and urban refugee sites are now widely acknowledged. These include rape and other forms of sexual violence, beatings, forced marriage and relationships, forced engagement in survival sex, and pregnancy and childbirth as a result of rape. ${ }^{2}$ However, there has been significantly less focus on and exploration of the risks and human rights abuses that refugee women and girls might 
face within countries of resettlement. Resettlement as a durable solution is predicated on the notion that the rights of those resettled will be restored and that, through effective settlement and integration support, the protection needs of refugees, including women and girls, will be addressed. ${ }^{3}$ Research in Australia, conducted over a number of years, has shown that some women and girls continue to be at risk of ongoing violence, human rights abuses, and threats to their safety and well-being during their settlement. Many of these experiences are directly related to and compounded by their previous experiences of sexual and gender-based violence that first identified them as women at risk. They include high risks of rape, forced relationships and marriage, survival sex, social exclusion, loss of confidence and self-esteem, and severe trauma. ${ }^{4}$

The United Nations High Commissioner for Refugees (UNHCR) Women at Risk (WaR) Program was created to provide resettlement to refugee women who had been identified by UNHCR as at extreme risk and in desperate need of resettlement. They were women "who, either due to their refugee status or to the social mores within the country of first asylum, as women find themselves seriously at risk." 5 In 1988 UNHCR commenced the program in partnership with non-governmental organizations (NGOs) for joint sponsorship of up to eighty "vulnerable" women in this new category. ${ }^{6}$ By 1992 two additional countries, Australia and New Zealand, had established WaR Programs. Each offered a modest number of places within their overall resettlement programs, with New Zealand offering twenty places and Australia sixty. Several other countries also started to accept women-at-risk cases within their resettlement programs. ${ }^{7}$

However, from its inception, the program struggled to achieve its aim, quotas were never filled, and many of the most at-risk women and girls were not resettled. Research undertaken by the authors over the past twenty-five years in Australia, and in refugee camps and urban settings in eighteen countries has identified some of the key barriers the program faces. These include difficulties in identification of at-risk cases, the dismissive attitudes of some NGO and UNHCR staff towards sexual and gender-based violence, and the low visibility of the program. The research documented not only the multiple risks and human rights abuses experienced by refugee women and girls, but also explored the challenges facing UNHCR and NGO staff in identifying WaR in situations where the vast majority of refugee women have experienced rape and sexual violence. ${ }^{8}$

One outcome of this research was the adoption of a new UNHCR Conclusion on the protection of women and girls at risk, first drafted by authors Pittaway and Bartolomei and adopted by member states at the Executive Committee Meeting of UNHCR Geneva in 2006.9 A Conclusion is "soft" international law designed to assist governments in their interpretation and implementation of the Refugee Convention. At the request of UNHCR and NGO field staff, they also developed a Women and Girls at Risk Identification Tool to assist in the identification of and response to atrisk women and girls. ${ }^{10}$ In 2007, Pittaway and Bartolomei worked with UNHCR Geneva and staff from Foundation House, Melbourne, to expand the tool to include other vulnerable refugee groups. The final tool was published by UNHCR as the Heightened Risk Identification Tool (HRIT) and adopted as a UNHCR standard operating procedure. It includes a comprehensive list of prevention and response mechanisms. ${ }^{11}$

Following the adoption of the Conclusion, UNHCR increased its focus on the identification and protection of refugee women and girls at risk. ${ }^{12}$ Although there is now stronger attention given to the identification and resettlement of WaR globally, there has been a limited focus on their settlement experiences. In particular, little is known about how previous incidents of risk and human rights abuses might affect women in settlement. ${ }^{13}$

This article examines the compounding impact that these experiences have on some women's abilities to find safety and security in countries of resettlement. Protection is an assumed and critical aspect of settlement and integration. Recognizing that specific definitions of protection vary in the context of forced migration and displacement, this article draws on those of UNHCR and the Office for the Coordination of Humanitarian Affairs. ${ }^{14}$ It argues that protection in the context of the settlement of refugee women at risk can be considered to focus on the reduction of risk and on the restoration, maintenance, and promotion of rights. However, services provided to newly arrived refugees often focus exclusively on the more practical aspects of settlement, such as the provision of housing, income assistance, and support for resettled refugees to build social connections and networks within their own community and with the wider community. ${ }^{15}$ It is clear from the research discussed below that before this can occur, the compounding impacts of the multiple risks, human rights abuses, and protection failures experienced by $\mathrm{WaR}$ prior to their resettlement have to be addressed.

The term women at risk is used extensively in program and policy documentation by both UNHCR and resettlement countries, including Australia. ${ }^{16}$ However, our research with refugee women in Australia ${ }^{17}$ suggests that this term is a misnomer. Rather than being "at risk," the majority of refugee women and girls have in fact already experienced significant and often multiple human rights abuses, directly linked to their gender. In this article the term women at risk refers to women who have experienced extensive abuses of 
their rights prior to settlement, who may have experienced further abuse once resettled, and who have an increased likelihood of experiencing further violations of their rights in the future.

This article draws on the findings from a number of linked research studies undertaken by the Centre for Refugee Research between 2003 and 2013, including a threeyear Australian Research Council-funded project Refugee Women at Risk: Protection and Integration in Australia. The aims of this research were to identify the extent and nature of risk experienced by WaR in Australia, and if appropriate, to develop a Heightened Risk Identification Tool for use in settlement. An evaluation was also undertaken of the capacity of settlement service-providers to meet the needs of WaR. Over 500 women and more than 100 service-providers participated in the research, which was conducted in three urban and four regional sites in New South Wales, Queensland, and Victoria.

In 2011, as part of the commemorations of the sixtieth anniversary of the Refugee Convention, the Centre for Refugee Research was commissioned by UNHCR to undertake a series of dialogues (community consultations) with over 1000 refugee and other displaced women in India, Colombia, Jordan, Uganda, Zambia, Thailand, and Finland. ${ }^{18}$ In each dialogue, participants identified significant risks and protection failures affecting the safety and security of women and girls. ${ }^{19}$ An eighth dialogue was also initiated with refugee women in Australia, and over 200 women participated. Sadly, the experiences of many women in settlement reported in this dialogue mirrored those shared by refugee women in the dialogues held overseas. In 2012, the research team was commissioned by a settlement organization in Australia to undertake an evaluation of services provided to refugee WaR. This research identified gaps in settlement responses to refugee women and again confirmed that women continued to be exposed to ongoing abuses of their rights once resettled.

\section{Research Methodology}

The qualitative methods employed in each of these studies included the participatory action research model named Reciprocal Research. ${ }^{20}$ It was developed by Pittaway and Bartolomei as part of their work examining the occurrence and impact of systematic rape and sexual abuse on refugee women and girls in camps and refugee sites overseas, and subsequently was adapted for work in Australia. The focus of the method is the collection of information in a way that is empowering, not harmful or exploitative, and has the potential to bring about social change. ${ }^{21}$ Both resettled refugee women and settlement service-providers participated in a series of community consultation workshops. The process involves using a human rights framework to set a context and to identify problems. Then situational analysis and possible response mechanisms are identified by the participants through the use of story circles ${ }^{22}$ and storyboards. ${ }^{23}$ The outcomes include a rich source of data, an identification of issues of concern based on the theme of the research project, a situational analysis, identification of appropriate and realistic solutions, and a strategic plan drawn up with the communities involved. ${ }^{24}$ Throughout this work, the data collected through the Reciprocal Research consultation was supported by individual in-depth qualitative interviews with refugee women and service-providers. In Australia, women who arrived under the Woman at Risk Visa Program, as well as other women who had suffered from sexual abuse and trauma as part of their refugee experience, participated in the research.

\section{The Women at Risk Program in Australia}

Australia is one of the few countries in the world to allocate a specific resettlement quota for women identified as being at risk and in urgent need of protection. In a strong show of commitment to this program, in 2009, the Australian government increased the quota to allocate 12 per cent of its refugee program intake to places for women at risk and their families. ${ }^{25}$ Each year since, approximately 780 women and their children have been resettled under the $204 \mathrm{WaR}$ visa program. In 2014, 1000 visa places are allocated for women at risk and their families as part of Australia's resettlement intake. ${ }^{26}$

Although the formal Women at Risk program is a crucial measure in meeting the needs of refugee women, our research has also identified that women resettled to Australia under other programs have often survived similar pre-arrival experiences, and that both groups encounter risks upon resettlement. ${ }^{27}$

UNHCR plays a critical role in the promotion of durable solutions, including facilitating the resettlement of the most at-risk refugees. However, once resettled, refugees no longer fall within UNHCR's protection mandate. Instead, the responsibility for the ongoing protection of refugee women rests with the government of the resettlement country. UNHCR provides considerable guidance to countries of resettlement on the provision of settlement services. ${ }^{28}$ In particular, they recognize that women resettled under the Women at Risk program will have experienced compounded protection risks and may face particular challenges in their settlement. UNHCR policy guidance states WaR will often require intensive specialized support to address traumatic experiences they have survived. Specifically it points to the absence of the critical support structures of family and community as key factors increasing the vulnerability of women 
in settlement to further abuses of their rights. ${ }^{29}$ UNHCR emphasizes the importance of gender-sensitive settlement planning, including health, education, employment, and housing services..$^{30}$

There is increased recognition that women who have experienced sexual and gender-based violence will require specialized psychosocial support. Most resettlement programs do emphasize appropriate psychosocial interventions, usually in the form of access to torture and trauma counselling. ${ }^{31}$ The Conclusion on Women and Girls at Risk ${ }^{32}$ highlights the importance of psychosocial support for women at risk in resettlement. However, to date there has been limited discussion of how a woman's pre-arrival experiences of sexual and gender-based violence might intersect with the risks and protection challenges she may encounter in the settlement environment.

WaR often require intensive and specialized torture and trauma counselling and other forms of psychosocial support to assist them in their settlement. However, the strong and often primary focus on mental health can limit the ability of resettlement countries to acknowledge and consider how women's experiences may affect other areas of settlement. In Australia, women at risk are able to access a range of on-arrival and short-term settlement services. Under the Humanitarian Settlement Services (HSS), orientation, case management and on-arrival accommodation services are provided. Women are also supported to access torture and trauma counselling and English classes. Between six and twelve months after arrival, women are "exited" from these on arrival services and encouraged to seek support through more generalist, long-term settlement services such as migrant resource centres. ${ }^{33}$ Although these services provide key support to many resettling women, this same assistance is available to the majority of refugees, with no specific services funded to respond to women at risk.

Settlement responses operate in silos, with specific services funded to respond to particular aspects of women's settlement needs. For example, a case worker will be assigned to assist with day-to-day needs; a separate housingprovider will take responsibility for on-arrival and longerterm accommodation; English classes are offered by another organization; and torture and trauma support are provided through a separate counselling service. Often there is limited communication between the services, resulting in challenges for women to receive the intensive, focused support needed. In addition the emerging emphasis on models of integration, such as that developed for the U.K. Home Office, focus on access to education, health services, employment, language skills, and the building of bridges between the newcomer and host communities. 34 They have little emphasis on the sequelae of pre-arrival experiences such rape, and sexual and gender-based violence on the ability of women to settle in a new country. They also do not recognize the vulnerability of resettled women at risk and the stigma that can isolate them, even within their own communities. This leads to a heightened need for family reunification, and yet this is not acknowledged as a critical part of their integration. The failure to understand the complex interplay of preand post-arrival experiences often places women at further risk.

Whilst committed to encouraging countries to both actively resettle and implement appropriate responses to support refugee women at risk, it is only recently that UNHCR has formally acknowledged that "after resettlement, refugee women often remain exposed to protection risks such as domestic violence, which can actually become worse in the new resettlement environment." 35 This recognition is critical. Although UNHCR correctly identifies domestic violence, this research has shown that there are many other risk and abuse factors that women and girls are exposed to during their displacement, which not only continue once they are resettled, but which intensify as they intersect with and are compounded by settlement challenges.

Recent research with resettled refugees examines the gender differences in access to employment and education and has demonstrated that men and women experience resettlement differently. However, few works have examined the compounding impact of women's exposure to protection risks at all stages of the refugee life cycle-from country of origin through to resettlement, and its relationship to integration. ${ }^{36}$ The compounding effect of multiple abuses can-and as this research has shown, does-make women more vulnerable to future violence and its impact on resilience and well-being. ${ }^{37}$

\section{Risk Factors for Refugee Women in Countries of Origin and Asylum}

They kill women in their own way.

-Resettled refugee woman (2010)

Women consulted for this research reported experiencing high levels of torture and trauma prior to arrival in Australia. This included systematic rape; sexual torture; forced witness of the rape of family members including their children; forced engagement in survival sex; birth of one or more children of rape; and rejection, violence, and isolation from their own communities.

They can come in your house, they can kill your husband, or your brother-all the men they can be killed. But they can't kill the women. But if there are twenty, all of them, they are going to pass 
to you [all rape you]. The rebel are going to do that, they don't care. And then the kids are just going to seeing what is happen.

-Resettled refugee woman (2009)

Participants reported that men and boys would sometimes be forced to witness the rape of their families before being killed. Women and girls suffered severe physical and emotional trauma from violence. Some committed suicide. Many became pregnant.

Violence and rights abuses continue in countries of asylum. Seeking refuge within camps and urban areas, women faced further risks, human rights abuses, and protection failures. Those without family or community support were particularly vulnerable. Some reported they were raped within days of arriving in a country of asylum. Often without shelter and with little or no food to feed their families, many were forced into survival sex to buy food, medicine, or shelter for themselves and their families.

Sometimes girls sell themselves, getting money to raise her brothers and she get pregnant ... In the camps it happens a lot. You don't have anything and there are men there who have money. What will you do?

-Resettled refugee woman (2011)

Women spoke frequently about the shame and risks associated with being a single mother or widow. They reported facing frequent harassment and abuse and were often targeted for rape and forced marriage. Survivors of sexual violence faced further shame, with many ostracized from their families and communities. Fear of such repercussions and an absence of effective law and justice systems meant many women did not even report the rapes. Those who did were often accused of lying, or their experiences were not taken seriously by protection agencies.

You will be shamed to tell people that this is going on. And people in the community will not understand: they will start to stigmatize you and reject you.

-Resettled refugee woman (2010)

Living with such fear and insecurity, some women were forced into relationships for protection, believing they would be less at risk than if they were alone. A number of women married men against their will after they had been raped or their families killed. Many of these relationships were violent and abusive, with women reporting frequent beatings and rape by their husbands or partners.

\section{Resettled but Still at Risk: The Experiences of Refugee Women in Australia}

All refugees, including refugee WaR, experience challenges in resettlement, including finding safe, affordable, and adequate housing, employment, and education. Many also experience racism and discrimination. Despite these obstacles, many WaR adapt quickly to their new homeland and settle successfully. However, others experience further risks and ongoing human rights abuses, including genderrelated violence. Women shared the fracturing impact of the shame associated with past and current experiences of human rights violations, on their relationships with family and communities. They explained how the risks they thought they had left behind have instead continued to affect them in Australia. These dangers then intersected with and compounded the new and emerging risks they faced in settlement. This was a major barrier to their ability to feel safe and secure and to settle successfully into their new country. As one resettled woman explained, "What happens there follows us here."

A major outcome from the research with WaR resettled in Australia was a framework to assist service-providers and policy-makers to identify and explore the particular characteristics and contexts that made some women more exposed to ongoing risk and human rights abuses in settlement.

Women and Girls Who Are Single, Pregnant, and without Family or Community Support

The stigma of being single causes many women to be isolated from their communities. Women and girls who become pregnant outside of marriage are often made to feel ashamed and ostracized. Without the support of family and community, women and girls are vulnerable to sexual abuse, harassment, and forced relationships.

What about single women? They are so much at risk. They struggle every day to resist rape. People know you are alone, and men try sexual abuse.

-Resettled refugee woman (2008)

\section{Women and Girls with a Child or Children Conceived from Rape}

Many women and girls are resettled with a child or children who have been conceived from rape. Some are pregnant through rape when they arrive. Others are raped and become pregnant here in Australia. These experiences are considered to be extremely stigmatizing for the women, and for their communities. Some women struggle to bond with their children because of the trauma and stigma associated with their conception and birth. This is sometimes 
so serious that it leads to interventions by child protection authorities. Women are often so shamed by these experiences they isolate themselves or are ostracized from their communities. This can make them vulnerable to further sexual abuse.

Rape is very much shamed in particular for the single mums. They usually have at least one child is a child of rape ... this means that sexual assault for single women is a huge, huge issue, particularly in terms of being [seen to be] available for married men to go to. -Settlement service provider (2011)

Women and Girls Who Are in a Forced Marriage, or Being Coerced into a Forced Marriage in Australia

The shame and stigma of being single and widowed often forces women into relationships in a bid to gain protection. They believe that if they are in a relationship it will make them less vulnerable to outside abuse and harassment and more accepted within their communities. At times, however, these relationships turn violent and women become trapped in unsafe partnerships.

Because the women who come here single are viewed as being inferior to those women who have come here with their husbands, there is still that sense that if they are in a relationship with someone, then they have the protection and giving their children a father figure, however appropriate or inappropriate, and it makes them feel like they are more respected in their communities.

-Settlement service-provider (2011)

Women and Girls Who Are Experiencing Rejection or Victimization by Their Own Community in Australia and Isolated from Their Own and Host Communities Because of Shame Factors

Single or widowed women who are known to have survived sexual violence or engaged in survival sex, those who are pregnant outside of marriage or who have left a relationship because of domestic violence-all report experiencing isolation. The shame and stigma of such experiences causes relationships within families and communities to fracture, leaving women without support. Women are also frequently isolated because of fears for their own safety. Isolation is worsened for women who do not speak the language and who cannot access support services. This is exacerbated when they suffer from mental health problems, which in turn increase the isolation.
And some of them ... being a woman under a 204 visa [are] ostracized from the community ... they know that you have been raped, ... and some people blame her, ... they have that bad image of her.

-Settlement service-provider (2012)

Women and Girls Who Are Suffering from

Misunderstandings and Conflict over Women's and

Children's Rights

The challenges of negotiating the different roles and expectations of women and girls has led to misunderstandings and misinterpretations of the meanings of rights and the ways in which they are reflected in the culture and legal frameworks of Australia. This confusion is reflected in refugee communities and among some service-providers. In all research sites, reports of family breakdown, intergenerational conflict, and the removal of children by child protection agencies have all been blamed on "human rights." This is putting extreme pressure on service-providers often not trained to deal with this level of complexity.

You can't just say you have your rights, you just say, "Rights, rights, rights." More education for women and children. That would help stop the culture shock ... The rights they have destroyed them.

-Resettled refugee woman (2009)

Such challenges to the key support and protection structures of family and community render many women and girls vulnerable to exploitation, stigmatization, and isolation and can act as additional barriers to their accessing much-needed services.

\section{Women and Girls Who Are Experiencing Increased} Vulnerability Due to Separation from Family Members Without family support, many women struggle to achieve successful settlement. They are often responsible for sending remittances back home to support loved ones who remain in danger. Traumatized by separation from their families, they experience enormous guilt for having been resettled. Many try to sponsor their families to come to Australia; however, the waiting list is long and the process expensive. Often their families are unaware that life in Australia is difficult and cannot understand why the women are not working harder for them to be reunited. Women described going without meals and engaging in exploitative employment, and survival sex, in order to earn money to send back to their families.

I can't sleep at night worrying about them, I can't concentrate in my English classes-I think about it every second of every day -Resettled refugee woman (2012) 
Women and Girls Who Are Living in Situations of Family and Domestic Violence

The stresses of settlement and the challenges of negotiating new gender roles for men and women contribute to and exacerbate domestic violence within refugee families. Women are often fearful of leaving these relationships because of the shame and stigma of divorce and of being a single woman. Many remain out of a sense that they will be better protected within the relationship than alone. Some are unaware they can leave. Others are fearful that if they do try to leave, the violence will worsen and they will have nowhere to go with their children. Refuges are often ill equipped to respond to the needs of refugee women with large numbers of children. Services and refugee communities are seeking culturally responsive models to support families experiencing domestic violence.

It's a challenge for the men too ... they don't get employment immediately, even for the skilled ones. [It] makes them feel like they're losing their power and they change, their roles are changing and they get frustrated. When they get frustrated, their family breakdown come, some of the things you people call family violence ... So the family violence because of the changing gender roles is there.

-Settlement service-provider (2010)

Women and Girls Who Are Suffering Impairment in Daily Functioning Due to Severe Psychological Trauma The endemic violence endured by many WaR can cause severe psychological trauma. Although many refugees experience trauma, the compounding impact of the multiple traumas women have endured, compounded by an absence of support networks and the ongoing risk of further violence in countries of resettlement, exacerbates their trauma. Many find it difficult to take care of themselves and their families. They sometimes distance themselves from loved ones, including their children, and act unpredictably. The effects of this trauma make it difficult for women to trust people and to feel safe. They can prevent women from accessing essential support services. They frequently refuse counselling support services because they are fearful of disclosing their experiences, feeling that they will be shamed or not believed. Others are afraid of being labelled "mad" or "cursed." In some cases, counsellors have been so traumatized by the women's experiences the women have refused to return to the service.

We always remember. It's not easy to forget ... You find lot of happiness in Australia but you are injured in the heart and you can not fix it. Trauma is still in your heart ... I may be smiling on the outside but I am crying on the inside.

-Resettled refugee woman (2009)

\section{Women and Girls Who Are Forced to Engage in Survival Sex}

Women who are known to have engaged in survival sex before arriving in Australia reported being targeted for abuse and harassment. They disclosed that men come to their homes demanding sex and rape them if they refuse. Once this becomes known in their communities, the women are ostracized. Other women reported being forced into survival sex because they were struggling to feed their families and pay the rent on their limited welfare payments. Often these women were also supporting family members still overseas.

The issue of sexual and gender-based violence, survival sex, rape in marriage, and so on ... : It doesn't stop when you arrive here in Australia.

-Resettled refugee woman (2011)

\section{Compounded Risk in Settlement: The Intersectionality of Protection Challenges in Settlement}

After honeymoon phase, many services is not enough. The challenges begin ... language barrier, financial hardship ... Time of resettling is full of stress ... Financial independence is a big, big one. Education, plus language barrier makes a problem-don't understand Australian system. Isolation is another problem. Finding a good stable job. Becoming more depressed.

-Resettled refugee woman (2012)

Intersectionality is a sociological theory that suggests and seeks to examine how various socially and culturally constructed categories, such as gender, race, class, disability, and other axes of identity, interact on multiple and often simultaneous levels and contribute to systematic social inequality. It has its theoretical origins in the work of African American and Third World feminists of the 1980 o and 1990 os $^{38}$ It is an analytical approach that explores the manner in which multiple oppressions and discriminations can interlock to compound the disadvantage and exclusion of marginalized peoples. ${ }^{39}$ The concept is drawn upon to aid in exploring and understanding the range of risks and oppressions that intersect in the lives of refugee women to compound their disadvantage and social exclusion in settlement.

Both women and services spoke often about the multiple protection risks and abuses women faced during settlement. 
Each risk and issue of concern was seen as intrinsically connected to another, serving to mutually compound and intensify the overall level of risk experienced by the women. As their level of risk heightened, their ability to access critical support services was lowered. The failure by some services to identify and respond to these risks in the early stages of settlement led to women being exposed to ongoing risks at later stages. For women at risk, settlement challenges that were perceived to be a normal part of the refugee settlement experience placed women at heightened risk, as they were unable to achieve these fundamental steps in settlement and integration. These include obstacles in gaining access to appropriate and affordable housing, language barriers, racism, and difficulties in accessing education and employment. Protection failures, where women are not able to access appropriate or effective service responses, further compound the level of risk experienced by women. As is discussed below, each protection problem and settlement challenge increases the vulnerability of refugee women and girls, leaving them open to further abuse.

Women are often unfamiliar with their rights and how the legal system works in Australia. Often their abusers in countries of asylum have been authorities, including police. Women are therefore fearful of reporting the rape because they are unsure where they can find protection and if they will be believed. As a result, women are frequently prevented from socializing or accessing employment or education opportunities. Women who are unable to learn English quickly as a result of the traumas they have experienced, are less likely to be able to be employed and therefore find it difficult to find safe and affordable housing for themselves and their children. This forces them to rent housing in unsafe neighbourhoods where they experience racism and discrimination and are isolated from community and services. It is difficult for services to reach them and for them to reach out to services.

Women who have been stigmatized as being "mad" by their communities because of severe mental health issues will frequently shy away from formal torture and trauma services. They may be fearful of engaging in social support networks because of past experiences of ostracism and shame. This makes them further isolated and exacerbates the mental trauma they are experiencing. Women are then alone and vulnerable to further sexual and gender-based violence. Stress causes family breakdown, and child protection authorities become involved. Women with children are fearful their children could be taken away because they have done something wrong.

Women resettled without their families struggle without this family support. They are often unable to attend English classes because they have no family support to look after their children, and even where child care may be provided, they may feel uncomfortable leaving them there because of past experiences of abuse and kidnap. Without English, the women cannot find a well-paying job. Women who are single parents may struggle with parenting and intergenerational conflict.

Women with a child or children conceived from rape struggle to trust and find acceptance within communities. As has been discussed above, the stigma of their previous experiences of sexual abuse also makes them less likely to trust and find support in services. As single parents, they may struggle to connect with their child. Discipline issues occur and child protection authorities become involved. The woman is labelled a bad mother and is viewed with suspicion by both her community and settlement services. The shame and stigma associated with sexual violence mean that neither the women nor the services working with them acknowledge these violations are happening. In situations where the abuse continues, women are further isolated and their physical and psychological trauma worsens.

\section{Notions of Shame}

Common to the finding of the research both in overseas sites and with refugee women in Australia, was the use of the word shame to describe a woman's, her family's, and her community's response to rape and sexual violence. It is perhaps the most common word in the discourse with refugee women who are raped and sexually abused, and for those who have been forced to undertake survival sex. 40

It is so pervasive that it often is used both to explain the silence about these issues and also to silence women and communities. It is freely used in translation from a number of different languages and yet seldom explored. ${ }^{41}$ In this research over 500 refugee women were interviewed, and these participants freely discussed the rape and sexual abuse that they and their communities had suffered. Most commented that many service-providers "stopped" them from talking about their experiences. In every site, women thanked the researchers, many commenting that this was the first time they had been listened to or given the opportunity to share their experiences.

This indicated the need for much deeper research and enquiry into the discourse on sexual and gender-based violence in refugee settings, and an exploration of the impact of form of these discussions has on the provision of effective protection. Preliminary analysis by the research team suggests that the word stigma would often be more appropriate than shame. The issue is complex. The shame assigned to the individual women is part of the collective consciousness of many communities, and they are often unable to cope with the horror of the events. Service-providers struggling 
to cope with the continuing stories of torture and extremely traumatized clients retreat and use the notion of "shame." At best they often silence women. At worst they accuse them of fabricating stories they themselves cannot cope with and the realities in which they are struggling to provide protection.

Until we can devise ways in which to effectively discuss and respond to these issues in countries of asylum as well as in countries of resettlement we are not going to be able to adequately respond to the needs of women at risk.

\section{Responses to Women at Risk}

Although it is acknowledged that all refugees require some form of assistance to settle well, in the case of WaR, it is obvious that more targeted specific responses are required.

Many service-providers are not equipped to deal with the multiple risks and abuses experienced by resettling refugee women. They are often unaware of the pre-arrival experiences and are not trained to develop complex case management plans that are crucial to address the intersecting problems with which they are faced. In developing effective responses to $\mathrm{WaR}$, workers must first recognize and acknowledge the impact of women's pre-arrival experiences. Despite the stigma that is often associated with this trauma, throughout this research it is the women themselves who have most actively sought recognition of these experiences. Recognizing the horror women have lived through, but also the considerable strength it takes to survive, is critical in helping women to build trust with their workers, and to feel safe and secure in their settlement.

If we acknowledge this part of their life [pre-arrival], they feel loved, safe, at beginning. These women will shine. It is so easy to ignore. To be honest, it's devastating. We know your background, we help you, we have your back, you have all our support, you are safe.

-Resettled refugee woman (2013)

Given these experiences, women reported that it took considerable time for them to trust they would be safe and to cope with rebuilding their lives in Australia. It is important therefore that services proceed slowly and take their time to identify and respond to the needs of women. Many women require long-term intensive support for at least two years after arrival. On arrival, services must be flexible, with opportunities for women to access extended support as required. This includes having access to long-term, safe, affordable housing, consistency in caseworkers, and a tailored approach to case management that incorporates opportunities for regular home visits as required. Women must be active participants in contributing to their case management plans. They may require support from a number of different organizations at the same time. It is essential that case managers coordinate these responses effectively. This will often require workers to have strong links with other agencies and to advocate on behalf of women. Effective and regular communication between services is key.

In the absence of family and community-support structures, settlement workers fill a considerable gap in women's lives. Women often look to their workers not simply for information and guidance, but also protection. They see workers as someone who will help restore their rights and who will keep them safe and well. It is therefore critical that workers are well trained and supported to respond. This includes targeted training on the impacts of trauma, and on the pre- and post-arrival experiences of women and girls from refugee backgrounds. The demands on such workers are often immense. They require access to regular debriefing and supervision to assist them to continue to provide the most effective support possible..$^{2}$

Refugee women also provide invaluable support to each other. The women spoke of the importance of sharing their experiences with other women from similar backgrounds. Women's support groups that could, with the support of local services, be led by refugee women were suggested as a way of providing a safe space for women to meet. Such groups would help women to cope with their trauma, to build trusted relationships, to break down isolation, and also to share their considerable strengths, skills, and knowledge with each other.

Services in Australia are strongly committed to supporting the settlement of women at risk. A number of successful models of response are emerging. The most effective are directly informed and led by the experiences of refugee women. Services that have employed resettled refugee WaR to act as "guides," to assist women in their settlement, have provided much-needed support. Organizations have also established specialist WaR committees whose membership includes resettled refugee women. The role of these committees is to provide advice on how services can best incorporate a gender lens in their work, to keep the needs of WaR visible, and to ensure that responses that are developed are effective and reflect the voices of the women.

Other services have incorporated specialist WaR workers into their case-management teams. They are female, are allocated only to WaR cases, and are trained in working with and responding to trauma and the specific needs of refugee women at risk. The knowledge and attitude of such workers are critical to helping women to settle well. In particular, it is important they understand and are open to discussing and responding to the impacts of sexual and gender-based 
violence and other forms of torture and trauma women may have experienced or continue to be experiencing once resettled.

It is also essential that mechanisms are in place to assist workers to identify and respond to the many and varied risks and abuses that women may be exposed to in the settlement environment. An important outcome from this research has been the development of a risk assessment and response tool for use in settlement.

\section{Risk Assessment and Response Tool}

Based on the Heightened Risk Identification Tool (HRIT) for use with at-risk populations in situations of displacement, this new identification and response tool is designed to assist service providers in countries of resettlement to identify those most at risk and in need of additional or alternative support, and to provide assistance in developing effective responses. ${ }^{43}$ It incorporates a more detailed listing of some of the potential risks for women in settlement. A key aspect of the tool is its recognition of the impact of multiple risks experienced by resettling women and girls and its links to pre-arrival experiences of rights violations. It provides detailed guidance to assist workers in preparing a comprehensive case management plan and includes suggested response pathways. The use of the tool depends on an understanding of the compounding nature of the risks faced by refugee women in resettlement, and on the power of the notions of "shame" which as highlighted earlier is so often used in the discourse surrounding women at risk. The risk assessment and response tool is currently being implemented with a number of settlement organisations.

It is clear that whilst considerable progress has been made in terms of recognising the needs of WaR in Australia, more work is needed to develop both policy and practice responses to ensure their ongoing protection. The authors are working closely with resettled refugee women and a number of settlement services in the design and development of a range of strengths based response models for working with WaR. These will build on the risk assessment and response tool outlined above, and the positive initiatives already taking place across the settlement sector in Australia.

\section{Conclusion}

We are happy and we hope that there will be no war in Australia and we hope that God will make our lives better ... we run from country to country to Australia and where else can we go? Better to die ... we hope that such a thing like that will not happen again. -Resettled refugee woman (2009)
Women at risk from refugee backgrounds are survivors and bring to countries of resettlement not only hope for a safe and peaceful existence but knowledge, strengths, skills, and resilience. Resettlement is a key protection for many at-risk women and girls; however, recognition must also be made that some continue to experience and be exposed to risks and abuses once resettled. Old and new risks merge and frequently compound to destabilize and challenge the safety of resettled women and girls. Failure to acknowledge these risks and a lack of effective response to their concerns significantly affects their ability to settle well in countries of resettlement. In spite of this adversity, WaR remain determined to rebuild their lives and to attain the rights to which they and their families are entitled. To achieve this end, many will require intensive specialized settlement support that respects and acknowledges their strengths while also recognizing and responding to the potential risks that threaten their well-being. In this regard, the recent and particular efforts of Australia's Department of Social Services 44 to focus on the settlement needs of WaR are acknowledged. This includes increased training for staff, a focus on resettling women without family connections to specific locations that have a strong history of supporting WaR, and providing funding for research into employment programs for WaR. ${ }^{45}$ It is hoped that such targeted efforts will indeed contribute to providing refugee women at risk and their children with the safety, security, and rights to which they are entitled upon resettlement to Australia.

\section{Notes}

1 Some participants from refugee backgrounds continue to remain at risk in Australia. Where necessary, identifying details have been amended to preserve their confidentiality.

2 Eileen Pittaway, Linda Bartolomei, and United Nations High Commissioner for Refugees, Survivors Protectors Providers: Refugee Women Speak Out, UNHCR, 2011, http://www .unhcr.org/refworld/docid/4f31obaa2.html; Susan F. Martin, "Introduction," in Women, Migration, and Conflict: Breaking the Deadly Cycle, ed. S. F. Martin and J. Tirman, 1-22 (London: Springer, 2009); Dale Buscher, "Refugee Women Twenty Years On," Refugee Survey Quarterly 29, no. 2 (2010): 4-20; Women's Commission for Refugee Women and Children, Displaced Women and Girls at Risk: Risk Factors, Protection Solutions and Resource Tools (New York: Women's Commission for Refugee Women and Children, 2006); Zermarie Deacon and Cris Sullivan, "Responding to the Complex and Gendered Needs of Refugee Women," Affilia 24 (2009): 272-84.

3 United Nations High Commissioner for Refugees (UNHCR), Resettlement Handbook (Geneva: UNHCR, 2011), http://www.unhcr.org/4a2ccf4c6.html. 
4 Centre for Refugee Research (CRR), Hear Our Calls for Action: Dialogues with Women from Refugee Backgrounds in Australia (Sydney: ANCORW and Centre for Refugee Research UNSW, Australia, 2011); UNHCR, Resettlement and Women-at-Risk: Can the Risk Be Reduced? (Geneva: UNHCR, 2013), http://www.unhcr.org/51de6e929.html; UNHCR, Handbook for the Protection of Women and Girls (Geneva: UNHCR, 2008), http://www.unhcr.org/protect/ PROTECTION/47cfae612.html; Eileen Pittaway, Refugee Women: Still at Risk in Australia (Canberra: Bureau of Immigration Research / Australian Government Publishing Service, 1991); Lenore Manderson, Margaret Kelaher, Milica Markovic, and Kerrie McManus, "A Woman without a Man Is a Woman at Risk: Women at Risk in Australian Humanitarian Programs," Journal of Refugee Studies 11, no. 3 (1998): 267-83.

5 Angela Gibbs Peart, "UNHCR and Refugee Women," Canadian Woman Studies 10, no. 1 (1989): 103.

6 Ibid.

7 Susan F. Martin, Refugee Women (London: Zed Books, 1992).

8 Eileen Pittaway and Linda Bartolomei, "Refugees, Race and Gender: The Multiple Discrimination against Refugee Women," Refuge 19, no. 6 (2001): 21-32; Eileen Pittaway and Linda Bartolomei, The Case for a Conclusion on Refugee Women at Risk, background document (Geneva: UNHCR, 2005); Pittaway, Bartolomei, and UNHCR, Survivors Protectors Providers.

9 UNHCR, "Conclusion on Women and Girls at Risk" UNHCR Executive Conclusions No. 105 (LVII), (Geneva: UNHCR, 2006).

10 Eileen Pittaway and Linda Bartolomei, Refugee Women at Risk Assessment Tool and Response Mechanism (Sydney: Centre for Refugee Research and ANCORW, 2005), http://www.crr.unsw.edu.au/research-projects/ completed-research/\#Women\%20at\%2oRisk.

11 UNHCR, Heightened Risk Identification Tool, and ed. (Geneva: UNHCR, 2010), http://www.unhcr.org/refworld/ docid/4c46c686o.html.

12 UNHCR, Resettlement Handbook.

13 UNHCR, Handbook for the Protection of Women and Girls; UNHCR, Resettlement and Women-at-Risk: Can the Risk Be Reduced? (USA: UNHCR, 2013), http://www.unhcr .org/51de6e929.html

14 Ibid.; UNHCR, Resettlement Handbook.

15 Alastair Ager and Alison Strang, "Understanding Integration: A Conceptual Framework," Journal of Refugee Studies 21, no. 2 (2008): 166-91; Department of Immigration and Citizenship (DIAC), Fact Sheet 66: Humanitarian Settlement Services Program (Canberra: Commonwealth of Australia, 2013).

16 UNHCR, Resettlement Handbook; DIAC, UNHCR Resettlement Handbook: Country Chapter-Australia (Canberra: DIAC, 2011), http://www.unhcr.org/3C5e542d4.html; DIAC, Getting Settled: Women Refugees in Australia (Canberra: Commonwealth of Australia, 2013).
17 Eileen Pittaway, Linda Bartolomei, and Rebecca Eckert, Refugee Women at Risk in Australia: An Assessment Tool and Response Mechanism for Settlement Services (Sydney: Centre for Refugee Research and ANCORW, 2014), http://www.crr.unsw.edu.au/research-projects/ completed-research/\#Women\%2oat\%2oRisk.

18 Pittaway, Bartolomei, and UNHCR, Survivors Protectors Providers.

19 Centre for Refugee Research, Hear Our Calls for Action: Dialogues with Women from Refugee Backgrounds in Australia (Sydney: Centre for Refugee Research and ANCORW, 2011), http://www.crr.unsw.edu.au/media/File/2011_Womens _Dialogue_Report.pdf.

20 Eileen Pittaway, Linda Bartolomei, and Richard Hugman, "When "Do No Harm' Is Not Enough: The Ethics of Research with Refugees and Other Vulnerable Groups," British Journal of Social Work 41, no. 7 (2011): 1271-87.

21 Peter Reason and Hilary Bradbury, Handbook of Action Research (London: Sage, 2006).

22 Using this technique, participants are invited to share stories of particular issues of concern they have identified that are then positioned within the human rights framework.

23 This technique involves participants creating a series of drawings to conduct situational analyses, including proposals for action, response, and interventions. Working in small groups, participants are invited to focus on a key issue of concern that has arisen from the stories circles, and to prepare a series of six pictures that analyze the issue.

24 Eileen Pittaway and Linda Bartolomei, "Research as an Advocacy Tool: Whose Problem Is It?" in Researching Refugees and Asylum Seekers: Ethical Considerations, ed. K Block, E. Riggs, and N. Haslam, 151-70 (Queensland: Australian Academic, 2013).

25 DIAC, "Getting Settled: Women Refugees in Australia," January 2014, https://www.dss.gov.au/our-responsibilities/ settlement-and-multicultural-affairs/publications/ getting-settled-women-refugees-in-australia.

26 Ibid.

27 Rebecca Eckert, Eileen Pittaway, and Linda Bartolomei, Resettled But Still at Risk: Women at Risk and Resettlement, ARRA Submission to UNHCR Geneva (Sydney: Centre for Refugee Research, 2008); Pittaway, Bartolomei, and Eckert, "Women at Risk Assessment Tool."

28 See UNHCR, Conclusion on Women and Girls at Risk; UNHCR, Refugee Resettlement: An International Handbook to Guide Reception and Integration (Geneva: UNHCR, 2002); UNHCR, The Integration of Resettled Refugees: Essentials for Establishing a Resettlement Programme and Fundamentals for Sustainable Resettlement Programmes (Geneva: UNHCR, 2013), http://www.refworld.org/docid/51b81dgf4 .html.

29 Ibid.

30 Ibid.

31 Ibid.

32 UNHCR, Conclusion on Women and Girls at Risk.

33 DIAC, Fact Sheet 66. 
34 Alison Strang and Alastair Ager, "Refugee Integration: Emerging Trends and Remaining Agendas," Journal of Refugee Studies 23, no. 4 (2010): 589-607; Ager and Strang, "Understanding Integration."

35 UNHCR, Handbook for the Protection of Women and Girls, 11.

36 See Susan F. Martin, Refugee Women, 2nd ed. (London: Zed Books, 2004); Celia McMichael, "Sadness, Displacement and Resettlement: Somali Refugee Women in Melbourne,"' in Asylum Seekers and Refugees in Australia: Issues of Mental Health and Wellbeing, ed. D. Barnes, 135-47 (Parramatta: Transcultural Mental Health Centre, 2003).

37 See Linda Bartolomei, Eileen Pittaway, and Emma Pittaway, "An Examination of the Role of Identity and Citizenship in the Experiences of Women in Kakuma Refugee Camp in Northern Kenya," Development 46, no. 3 (2003): 87-93; Pittaway and Bartolomei, "Refugees, Race and Gender," 21-32; Pittaway, Bartolomei, and Eckert, Refugee Women at Risk in Australia.

38 bell hooks, Feminist Theory from Margin to Center (Boston: South End, 1984); Patricia Hill Collins, Black Feminist Thought: Knowledge, Consciousness, and the Politics of Empowerment (London: Unwin Hyman, 1991); Kimberley Crenshaw, "Mapping the Margins: Intersectionality, Identity Politics, and Violence against Women of Color,"' in The Public Nature of Private Violence, ed. M. A. Fineman and R. Mykitiuk, 93-118 (New York: Routledge, 1994); Chandra Mohanty, Feminism without Borders: Decolonizing Theory, Practicing Solidarity (Durham: Duke University Press, 2003).

39 Eileen Pittaway and Susan Rees, "Multiple Jeopardy: Domestic Violence and the Notion of Cumulative Risk for Women in Refugee Camps," Women against Violence 18 (2006): 18-25; Susan Rees and Bob Pease, Refugee Settlement, Safety and Wellbeing: Exploring Domestic and Family Violence in Refugee Communities (Melbourne: Immigrant Women's Domestic Violence Service, 2006).

40 Karen Women's Organisation (KWO), Shattering the Silences: Karen Women Speak Out about the Burmese Military Regime's Use of Rape (Thailand: KWO: 2004); Lana Zannettino, "Refugees, Sexual and Domestic Violence and Prior Experiences of Trauma: Introduction and Context," in Improving Responses to Refugees with Multiple Trauma: Pointers for Practitioners in Domestic and Family Violence, Sexual Assault and Settlement Service, Practice Monograph 1, 5-9 (Sydney: Australian Domestic and Family Violence Clearing House, 2013), http://www.adfv.unsw.edu.au/documents /PracticeMonograph_1.pdf.

41 Eileen Pittaway and Rebecca Eckert, "Domestic Violence, Refugees and Prior Experiences of Sexual Violence: Factors Affecting Therapeutic and Support Service Provision," in Improving Responses to Refugees with Multiple Trauma, 10-13.

42 Kim Robinson, "Voices from the Front Line: Social Work with Refugees and Asylum Seekers in Australia and the
UK," British Journal of Social Work 44, no. 6 (March 2013): $1-19$.

43 The tool can be obtained from the University of New South Wales, Centre for Refugee Research, at http://www. crr.unsw.edu.au/research-projects/completed-research /\#Women\%20at\%2oRisk; Pittaway, Bartolomei, and Eckert, Refugee Women at Risk in Australia.

44 In 2013, responsibility to provide settlement support for resettled refugees shifted from what was known as the Department of Immigration and Citizenship (DIAC), to the Department of Social Services (DSS).

45 DIAC, Getting Settled.

Linda Bartolomei is the director of the Centre for Refugee Research at the University of New South Wales, Australia. Her research includes projects related to refugee protection and community development in New Delhi, social capital and refugee settlement in Australia, and the protection and resettlement of refugee women and girls at risk. She may be reached atlinda.bartolomei@unsw.edu.au.

Rebecca Eckert is a senior research associate with the Centre for Refugee Research at the University of New South Wales, Australia. Her research is focused on the identification of and response to risks and human rights abuses experienced by refugee women in settlement, and the development of indicators of successful settlement for refugee women at risk. She may be reached at rebecca.eckert@unsw.edu.au.

From 1999 to 2013 Eileen Pittaway was director of the Centre for Refugee Research, and associate professor in the School of Social Sciences at the University of New South Wales, Australia. She now continues her involvement with the University in an honorary capacity. Her major research foci are the prevention of and response to the rape, sexual abuse, and gender-based violence experienced by refugee women at risk, both overseas and following resettlement to Australia, and the ethics of research with vulnerable populations. She may be reached at e.pittaway@unsw.edu.au

The authors would like to thank Rochelle Baughan, Effie Mitchell, and Geraldine Doney for their invaluable assistance with research and editing of this article.

Most importantly thank you to all of the refugees who so courageously shared their stories, and to the service providers who work tirelessly to support the settlement of refugee women at risk.

The research detailed in this paper was funded as part of an Australian Research Council-funded project (LP0776591, 2008-11) titled "Refugee Women at Risk: Protection and Integration in Australia," based at the Centre for Refugee Research, University of New South Wales, Sydney, Australia. 